\title{
(5)

\section{Smerter og smertebehandling de første to ukene etter store skader}

KORT RAPPORT

\section{GYDA ØSTLI}

E-post: gyda.ostli@gmail.com Akershus universitetssykehus

Hun har bidratt med idé, datainnsamling, databehandling og manuskriptbearbeiding. Gyda Østli er lege i spesialisering del 1 . Forfatteren har fylt ut ICMJE-skjemaet og oppgir ingen interessekonflikter.

\section{JOHAN RAEDER}

Avdeling for anestesiologi Oslo universitetssykehus, Ullevål

og

Institutt for klinisk medisin

Universitetet i Oslo

Han har bidratt med idé, databehandling og manuskriptskriving.

Johan Ræder er spesialist i anestesiologi, overlege og professor.

Forfatteren har fylt ut ICMJE-skjemaet og oppgir ingen interessekonflikter.

\section{BAKGRUNN}

Sterke smerter etter store skader har tradisjonelt vært behandlet med opioider. Vi ønsket å undersøke forekomsten av smerte hos pasienter ved vårt traumesenter, type smertebehandling de første to ukene etter innleggelse og videre planer knyttet til smertebehandling ved utskrivning.

\section{MATERIALE OG METODE}

Studien inkluderte 40 voksne pasienter som hadde store skader og var bevisste ved innleggelse. Data ble innhentet fra traumeregisteret ved Oslo universitetssykehus, fra pasientjournaler og fra intervju med alle pasientene omtrent to uker etter skaden. Pasientene ble spurt om å angi smerteintensitet fra o til 1o på en verbal numerisk skala (verbal numeric rating scale, VNRS).

\section{RESULTATER}

Hos 38 \% var gjennomsnittlig smerteskår i hvile høyere enn 3 i toukersperioden etter skaden, og 48 \% oppga å ha hatt skår høyere enn 3 over halvparten av denne tiden. Alle pasientene ble behandlet med opioider og paracetamol under sykehusoppholdet. I tillegg fikk 78 \% epiduralanalgesi eller nerveblokader, $35 \%$ fikk ketamin, $28 \%$ ikke-steroide antiinflammatoriske midler (NSAID), $23 \%$ alfa-2-agonister og $10 \%$ gabapentinoider. $78 \%$ ble utskrevet med opioider, uten at det var nedfelt en plan for nedtrapping i noen epikriser. 
Hardt skadde pasienter opplever mye smerte de første to ukene etter skaden.

Smertebehandlingen i sykehus kan forbedres, og det bør legges planer for opioidbruk og seponering etter utskrivning.

Etter store skader vil fokus i første omgang være knyttet til kirurgisk behandling og livreddende tiltak. I studier av denne tidlige fasen er det rapportert sterke smerter hos mer enn $50 \%$ av bevisste pasienter $(1,2)$. Det er også rapportert høy forekomst av langvarig smerte hos hardt skadde pasienter (3). I en studie fra Oslo universitetssykehus i 2007 opplevde $62 \%$ av hardt skadde pasienter sterk eller meget sterk smerte under sykehusinnleggelsen, og $24 \%$ hadde alvorlig langvarig smerte etter seks år (3). Smertebehandlingen i tidlig fase var i stor grad begrenset til opioider.

I denne aktuelle studien ønsket vi å undersøke intensitet av smerte de første to ukene etter store skader, hvilke smertelindrende metoder og medikamenter som ble benyttet, samt planlagt bruk av smertelindring etter utskrivning fra sykehus.

\section{Materiale og metode}

Studien ble utført ved Akuttklinikken, Oslo universitetssykehus, Ullevål, i tidsperioden juni 2018 - mars 2019. Studien ble av Regional etisk komité klassifisert som en kvalitetssikringsstudie og var derfor utenfor deres mandat. Studien er godkjent av Personvernombudet ved Oslo universitetssykehus (saksnummer 17/1740) og registrert på clinicaltrials.gov (registreringsnummer NCT 03730272).

Pasientene ble vurdert for mulig inklusjon ved daglig gjennomgang av traumeregisteret ved Oslo universitetssykehus. Inklusjonskriteriene var alder over 17 år, direkte mottak fra skadested av vårt traumeteam, ISS-skår høyere enn 8 samt at pasientene var samtykkekompetente og kunne kommunisere greit på norsk eller engelsk. Injury Severity Score (ISS) har en skala fra o til 75, og skåren beregnes ved å gradere skadens alvorlighet fra 1 til 6 i hver av seks kroppsregioner, kvadrere hvert siffer og deretter summere de tre høyeste tallene. En ISS-skår på 9 kan bety moderat skade i to forskjellige deler av kroppen eller én moderat til alvorlig skade ett sted.

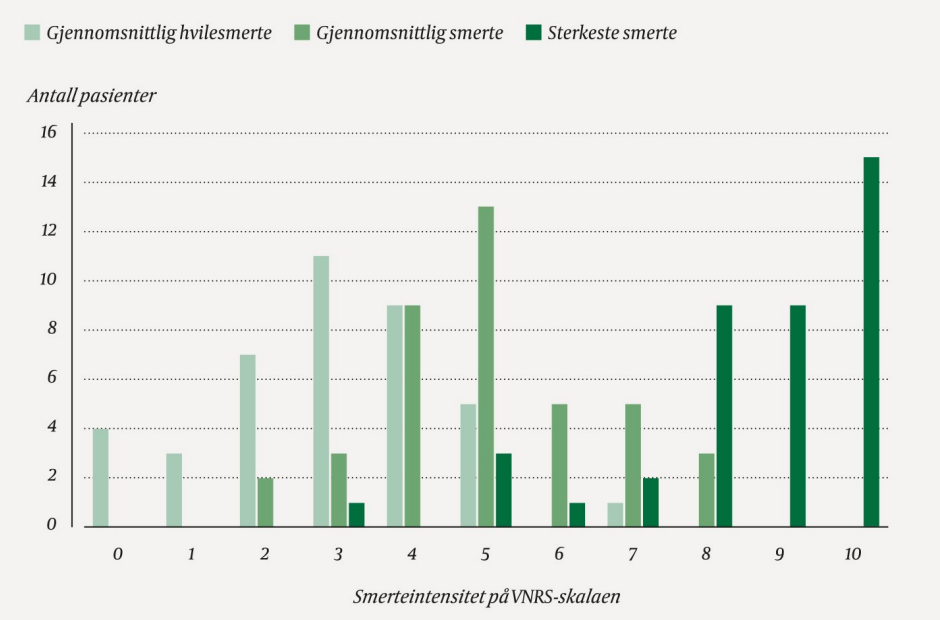

Figur 1 Smerteintensitet hos hardt skadde pasienter $(N=40)$ angitt med verbal numerisk skala (VNRS), som går fra o (ingen smerte) til 10 (verst tenkelige smerte). Oversikt over pasientenes gjennomsnittlige hvilesmerte, sterkeste smerte og gjennomsnittlige smerte $i$ en toukers periode etter skadetidspunktet.

Vi ekskluderte pasienter som var intubert, hadde isolert hodeskade, Glasgow Coma Scaleskår lavere enn 9, høyt spinalt tverrsnittsyndrom, kjent rusbrukslidelse eller som ble utskrevet innen seks timer. 
Det ble innhentet skriftlig informert samtykke, og data ble samlet fra pasientjournaler, traumeregister og pasientintervju. Intervjuet ble utført gjennomsnittlig to uker ( $95 \%$ innenfor 11-17 dager) etter skadetidspunktet. Pasientene ble spurt om smerteopplevelse i etterkant av skaden. For smerteintensitet ble det spurt om gjennomsnittlig smerte, gjennomsnittlig smerte i hvile og den verste opplevde smerten gjennom hele toukersperioden, angitt på en verbal numerisk skala (VNRS) fra o til 10 (o = ingen smerte, 10 $=$ verst tenkelige smerte). For angivelse av tid med smerte ble det spurt om samlet varighet med smerteskår høyere enn 3 .

Det ble spurt om administrasjon av smertelindring i perioden frem til og med intervju, og svarene ble sjekket mot journal og epikrise. Sykehusforskrevet smertelindrende medikasjon for tiden etter utskrivning ble registrert. For alle pasienter ble epikrise lest, med henblikk på forskrivning av opioider og eventuell plan for nedtrapping eller seponering.

\section{Resultater}

Ved sjekk av pasientlistene ble totalt 64 pasienter vurdert som aktuelle kandidater for studien. 22 av disse ble ekskludert, og av de 42 forespurte takket to pasienter nei til deltakelse.

Av de 40 inkluderte pasientene var 30 menn. Gjennomsnittlig alder var 46 år (variasjonsbredde 25-82 år), og gjennomsnittlig ISS-skår var 17 (9-30).19/40 (48\%) pasienter hadde skadet seg i forbindelse med trafikkulykker, og 33/40 (83\%) hadde stumpe traumer.

Ved intervjuet var 33/40 (83\%) utskrevet. 35/40 (88\%) oppga en gjennomsnittlig smerte gjennom toukersperioden høyere enn 3 på VNRS-skalaen, og av disse skåret 13/40 (33\%) over 5. Hos 15/40 (38\%) hadde gjennomsnittlig hvilesmerte vært høyere enn 3. 19/40 (48\%) oppga å ha hatt smerteskår over 3 over halvparten av tiden etter skaden.

Alle pasientene ble behandlet med opioider og paracetamol under innleggelsen, og 31 av 40 (78\%) fikk epiduralanalgesi eller nerveblokader, 14/40 (35\%) fikk ketamin, 11/40 (28\%) NSAID-midler, 9/40 (23\%) alfa-2-agonister og 4/40 (10\%) gabapentinoider. Ved utskrivning ble følgende analgetika forordnet til videre bruk: paracetamol til 31/40 (78\%), opioider til 31/40 (78\%), NSAID-midler til 3/40 (8\%), gabapentinoider til 2/40 (5\%) og alfa-2-agonister til 4/40 (10 \%). På intervjutidspunktet brukte 29/40 (73\%) opioider. Ingen epikriser inneholdt plan for nedtrapping eller avslutning av opioidbehandlingen.

\section{Diskusjon}

I denne studien av bevisste, hardt skadde pasienter fant vi at $88 \%$ hadde gjennomsnittlig smerteskår større enn 3 på VNRS-skalaen gjennom de første to ukene etter skaden. I hvile hadde $38 \%$ høyere gjennomsnittsskår enn 3, noe som tilsvarer moderat til sterk smerte. Dette til tross for at alle hadde fått smertestillende behandling med paracetamol og opioider, hos $78 \%$ supplert med epiduralanalgesi eller nerveblokade.

Selv om nerveblokade er meget effektivt som smertelindring, vil slik behandling vanligvis bli benyttet for en kortere periode rett etter skaden og vil ikke forhindre smerte i tiden etter dette (4). Hos 78 \% ble opioider forskrevet til bruk etter utskrivning, men ingen pasienter fikk journalført noen råd knyttet til nedtrapping eller seponering av opioider. Vi vet ikke hva slags muntlig informasjon pasientene fikk, men dette er i lys av den aktuelle diskusjonen om opioidmisbruk et viktig forbedringspunkt. Det er vist i et svensk materiale at risikoen for opioidmisbruk var mer enn tre ganger så stor hos dem som hadde vært utsatt for skade enn hos kontrollpopulasjonen (5). Spesielt langvarig bruk etter utskrivning etter en skade eller operasjon er assosiert med økt fare for misbruk (6).

En svakhet ved vår undersøkelse er at pasientene kun ble spurt om å vurdere smerte retrospektivt etter en toukers periode med en varierende og over tid synkende smerteintensitet hos de fleste. Mens vi under innleggelsen og på intervjutidspunktet kunne registrere hvilken behandling som faktisk ble gitt, vet vi ikke i hvilken grad det som ble 
ordinert ved utskrivning faktisk ble benyttet ut over toukersperioden. Et blandet traumemateriale, slik som vårt, har en overvekt av unge menn og personer med psykososiale problemer (3).Våre funn rundt smerte og smertereaksjoner er derfor ikke helt overførbare til den generelle befolkningen.

Vår konklusjon er at mange traumepasienter har mye smerter etter store skader og at det er potensial for å bedre dette med $ø$ kt bruk av ikke-opioide analgetiske medikamenter. Dette er viktig både for å redusere unødig lidelse og for å redusere bruk av opioider. Pasienter og fastleger bør få informasjon om nedtrapping og seponering av opioider etter utskrivning fra sykehuset.

\section{HOVEDFUNN}

Alle pasienter med store skader fikk opioider og paracetamol under sykehusoppholdet. 31 av 40 pasienter ble utskrevet med opioid smertebehandling uten at det var lagt noen plan for nedtrapping eller seponering.

I de to første ukene hadde 15 pasienter en gjennomsnittlig hvilesmerte høyere enn 3 på en verbal smerteskala fra o til 10.

\section{LITTERATUR:}

1. Berben SA, Schoonhoven L, Meijs TH et al. Prevalence and relief of pain in trauma patients in emergency medical services. Clin J Pain 2011; 27: 587-92. [PubMed][CrossRef]

2. Farčić N, Barać I, Pačarić S et al. Acute postoperative pain in trauma patients - The fifth vital sign. Open Access Maced J Med Sci 2017; 5:310-5. [PubMed][CrossRef]

3. Kolstadbraaten KM, Spreng UJ, Wisloeff-Aase K et al. Incidence of chronic pain 6 y after major trauma. Acta Anaesthesiol Scand 2019; 63: 1074-8. [PubMed][CrossRef]

4. Holmberg A, Sauter AR, Klaastad $\emptyset$ et al. Pre-operative brachial plexus block compared with an identical block performed at the end of surgery: a prospective, double-blind, randomised clinical trial. Anaesthesia 2017; 72: 967-77. [PubMed][CrossRef]

5. von Oelreich E, Eriksson M, Brattström O et al. Risk factors and outcomes of chronic opioid use following trauma. Br J Surg 2020; 107: 413-21. [PubMed][CrossRef]

6. Brat GA, Agniel D, Beam A et al. Postsurgical prescriptions for opioid naive patients and association with overdose and misuse: retrospective cohort study. BMJ 2018;36o: j579o. [PubMed][CrossRef]

Publisert: 25. januar 2021. Tidsskr Nor Legeforen. DOI: 10.4045/tidsskr.20.0450

Mottatt 18.5.2020, første revisjon innsendt 8.8.2020, godkjent 23.11.2020.

(C) Tidsskrift for Den norske legeforening 2020. Lastet ned fra tidsskriftet.no 